DOI 10.15393/j9.art.2018.5601

УДК 82.161.1.09“18”

Юлия Николаевна Сытина

(Москва, Российская Федерация)

yulyasytina@yandex.ru

\title{
«Русь, куда ж несешься ты?»: от «птицы-тройки» до железной дороги (Гогодь, Достоевский и другие)*
}

Аннотация. Реформы Петра I привели Россию к стремительному развитию как в материальной, так в интеллектуальной и эстетической областях. В XIX в. с особой остротой встал вопрос о выборе страной дальнейшего пути, к 1840-м гг. он получил историософское осмысление в спорах западников и славянофилов, отразившихся как в критике, так и в художественных произведениях. Путь России в метафорическом плане прочно связался с мотивом движения, в «Мертвых душах» Гоголя он получил символическое выражение в образе несущейся Руси-тройки, субстанциальность которой подчеркнул К. С. Аксаков, дав восторженную оценку финалу поэмы. В споре с критиком-славянофилом «западник» Белинский предложил альтернативный символ России, отсылающий не к прежней «святой Руси», а к обновленной «прогрессом» - символ железной дороги. Художественной репликой в адрес гоголевской тройки стал «Тарантас» В. А. Соллогуба, где пророческий пафос финала «Мертвых душ» высмеивается исходя из прагматического здравого смысла, с точки зрения которого сама проблематика споров о пути России умозрительна и несостоятельна. В дальнейшем в полемику включился Достоевский, вновь актуализировав образы живой тройки и механической железной дороги. В его реализме «в высшем смысле» они разрастаются в символы уже не просто разных путей развития России, но двух начал бытия: органического и - при всем безудержье, стремящегося к святости, - и мертвого, инфернального. В главном же Достоевский сходится с Гоголем: основополагающим у него также оказывается пасхальный архетип, свойственный всей русской культуре.

Ключевые слова: Н. В. Гоголь, Ф. М. Достоевский, В. А. Соллогуб, В. Г. Белинский, образ тройки, символика пути и движения, историософия, западники и славянофилы

$\left\{\begin{array}{l}\text { а XVIII и первую половину XIX вв. Россия проделает } \\ \text { огромный путь как в материальном, так в интеллектуаль- }\end{array}\right.$ ном и эстетическом плане. Стремительность развития будет очевидна уже современникам, перед которыми встанет вопрос о том, куда же ведет это бурное развитие, в какое русло его 
направить? «Куда ж нам плыть?» ${ }^{1}-$ задастся вопросом лирический герой Пушкина, и вопрос этот чем далее, тем более будет осмысляться по отношению ко всей России. Путь страны в художественно-символическом плане связывается с движением: и корабля, и «телеги жизни», прежде всего, тройки. Этот образ мыслился в метафизическом плане в поэзии А. С. Пушкина («Бесы»), П. А. Вяземского («Зимние карикатуры»), Ф. Н. Глинки («Сон Русского на чужбине») и других (см.: [Вранчан], [Кошелев], [Мароши]), однако именно у Н. В. Гоголя он субстанциально соединится с Россией, станет ее символом.

Проблема выбора исторического пути России теснейшим образом связана с вопросом о соотношении России и Европы (см.: [Захаров, 2013], [Русская классическая литература...]). Запад в XIX в. воспринимается русской общественностью по-разному: и как безусловный ориентир для России, и как источник ценных знаний и обычаев, к которому нужно прислушиваться, но с оглядкой, живя своим умом, и как абсолютное зло, причем порою даже в апокалиптическом, мистическом ключе. К 1840-м гг. вопрос этот окончательно обретет историософскую глубину: с одной стороны, стремление к древнерусским истокам усилится в трудах и произведениях славянофилов, а с другой - ослабится у западников, увлеченных идеями прогресса и единства развития мирового исторического процесса - европоцентризмом.

Гоголь, будучи прежде всего художником, подобно Пушкину или Лермонтову, не касается непосредственно темы европейского влияния на Россию - не выносит своего суда на этот счет, - славянофильские и западнические интенции сливаются у него в единстве русской жизни, в ощущении ее сложности и неисповедимости. Как представляется, даже в «Тарасе Бульбе», поэтизируя казачество, собственную правоту и эстетическую привлекательность писатель находит также у католиков-ляхов. Недаром не только мать Остапа и Андрия, но и прекрасная полячка молится Богородице, и эта «общая» молитва, «как и героизация противника, а не только самих казаков», позволяет говорить о том, что в повести «изображается братоубийственная война» [Есаулов, 2016: 282]. 
Вместе с тем, вопрос о судьбе России глубоко волновал писателя. Разъезды Чичикова, изначально носящие сугубо бытописательный характер, чем далее, тем более приобретают метафорические оттенки, в финале первого тома «Мертвых душ» развертываясь «в символический образ, включающий в себя традиционные для русского культурного сознания мифологемы» [Маркович: 165]. Этот заключительный аккорд восхитил славянофила К. С. Аксакова, увидевшего в лирических отступлениях Гоголя мерцание самой «тайны» русской жизни:

«Чичиков едет в бричке, на тройке; тройка понеслась шибко, и кто бы ни был Чичиков, хоть он и плутоватый человек, и хоть многие и совершенно будут против него, но он был русский, он любил скорую езду, — и здесь тотчас это общее народное чувство, возникнув, связало его с целым народом, скрыло его <...>. И когда здесь, в конце первой части, коснулся Гоголь общего субстанциального чувства русского, то вся сущность (субстанция) русского народа, тронутая им, поднялась колоссально, сохраняя свою связь с образом, ее возбудившим. Здесь проникает наружу и видится Русь, лежащая, думаем мы, тайным содержанием всей его поэмы» [Аксаков: 9-10].

Западнически настроенный В. Г. Белинский отнесся к подобной трактовке с едкой иронией, заметив, что «субстанции русского народа» он не видит «ни в тройке, ни в телеге». Даже более удобной «коляске четвернею» Белинский предпочитает железную дорогу:

«Иначе и быть не может: свет победит тьму, просвещение победит невежество, образованность победит дикость, а железными дорогами будут побеждены телеги и тройки» [Белинский, 1955: 429-430].

Железная дорога становится для критика символом преобразований и прогресса, и символ этот закрепится в русской литературе.

Новые эпохи рождают новые интерпретации финала «Мертвых душ». В инфернальном ключе, припоминая «тройки» Поприщина и Хлестакова, рассматривает его Д. С. Мережковский, по мнению которого «ужасной, неожиданной для самого Гоголя насмешкой звучит его сравнение России с несущеюся 
тройкой» [Мережковский: 31]. Тоже негативно, но в совершенно ином ключе воспринимается финал «Мертвых душ» «простым человеком» XX в. - героем рассказа В. Шукшина «Забуксовал». У него вызывает недоумение, как можно восхищаться тройкой, в которой мчится «прохиндей, шулер» ${ }^{2}$ Чичиков? B. А. Кошелев объясняет такое восприятие тем, что в поэзии XIX в. «возникший в народной песне и закрепившийся в народном сознании образ тройки выступал как семантически самодостаточный и как будто не предполагал, что в тройке может находиться еще какой-то “путник”» [Кошелев: 149]. Исследователь сводит финал к чисто художественному поэтическому приему: «И не все ли равно, кто едет в конкретной русской “тройке” - Чичиков или какой-нибудь Правдин важна сама поэзия движения...» [Кошелев: 150]. Таким образом, в интерпретации В. А. Кошелева та соборность, которую подчеркивает К. С. Аксаков, превращается в исчезновение личностного начала вообще, утверждение его избыточности.

Анализируя историю интерпретаций образа гоголевской тройки, В. В. Мароши отмечает его амбивалентность, настаивая на том, что ее задает сам текст произведения: «Двусмысленность символа позволяет увидеть в нем как негативный, так и позитивный аспект, в зависимости от позиции интерпретатора и прагматики истолкования <..> смысловая контроверсивность этого фрагмента поэмы задана внутри самого гоголевского текста» [Мароши: 205]. Традицию негативной интерпретации гоголевской тройки исследователь возводит к спору прокурора и адвоката в «Братьях Карамазовых»: «Именно в этих прениях тройка впервые была вполне резонно сопоставлена с бричкой Чичикова» [Мароши: 205].

Иначе, в контексте «большого» времени русской культуры и исходя из первоначального замысла Гоголя о трехчастной структуре поэмы в соответствии с «Божественной комедией» Данте, предлагает понимать финал «Мертвых душ» И. А. Есаулов: «Как представляется, пространственная горизонталь тела России (“ровнем-гладнем разметнулась на полсвета”), преодолевая апостасию - в символе Руси-тройки, должна преобразиться в соборную духовную вертикаль». Это преображение в финале «Мертвых душ» осмысляется Гоголем как 
«Божие чудо» и имеет, по мнению И. А. Есаулова, «отчетливый пасхальный смысл»: «в финале “Мертвых душ" происходит пасхальное чудо воскресения "мертвого душою” центрального персонажа гоголевской поэмы» [Есаулов, 2017: 153-154]. Доказательства такого понимания гоголевского текста исследователь находит и в «Выбранных местах из переписки с друзьями», указывая на пасхальность, заложенную в самой структуре этого произведения, идущего от «Завещания» к «Светлому Воскресению» (см. также: [Есаулов, 1994]).

Именно в «Выбранных местах...» Гоголь обращается и непосредственно к разгоревшимся в 1840-е гг. спорам «о наших европейских и славянских началах», однако и здесь не становится однозначно на сторону западников или славянофилов, но явное предпочтение отдает «славянистам и восточникам», ближе к которым он был и в жизни (см. подробнее: [Виноградов, 2014, 2017]).

Гоголь подчеркивает различия, существующие между православной Россией и католическим по преимуществу Западом, но и русское, и европейское современное общество представляется ему ложно-рациональным, мертвенным, утратившим подлинную святость и гармонию, живую органичность. Размышляя о России, Гоголь выделяет два пласта понимания то, какова реальная Россия сейчас, и то, какой она могла бы явить себя миру, благодаря заложенным в ней силам. Именно на освящение путей к духовному преображению каждого человека и всей Руси-тройки и направлены поучения в письмах к друзьям.

Возможность обретения чаемой святости и должного земного уклада Гоголь усматривает в действительном - в прорывающемся сквозь повседневность - пасхальном божественном свете (см. подробнее: [Есаулов, 2004]). В заключительной главе «Светлое Воскресение» писатель размышляет об «особенном участии к празднику Светлого Воскресенья» в русском человеке, и не потому, что русский народ «лучше» (подобно Чичикову: «хуже мы всех прочих» (Гоголь, 8; 417)), но потому, что «есть много в коренной природе нашей, нами позабытой, близкого закону Христа», и самая неустроенность «пророчит» возможность обновления и великого будущего: 
«Мы еще растопленный металл, не отлившийся в свою национальную форму; еще нам возможно выбросить, оттолкнуть от себя нам неприличное и внести в себя все, что уже невозможно другим народам, получившим форму и закалившимся в ней» (Гоголь, 8; 417).

Осознание греховности должно привести к ее преодолению, и тогда окажется возможным «сбросить с себя все недостатки наши, всё позорящее высокую природу человека», когда - во время пасхального торжества - «вся Россия - один человек» (Гоголь, 8; 417).

Описывая же теперешнюю неустроенность и бесприютность, Гоголь, как и в поэме, обращается к образу дороги и несущейся по ней тройки, но на этот раз движение исчезает, прежние лошади утомились:

«...будто бы мы до сих пор еще не у себя дома, не под родной нашею крышей, но где-то остановились бесприютно на проезжей дороге, и дышит нам от России не радушным, родным приемом братьев, но какой-то холодной, занесенной вьюгой почтовой станцией, где видится один ко всему равнодушный станционный смотритель с черствым ответом: “Нет лошадей!"» (Гоголь, 8; 289; курсив мой. - Ю. С.).

Образ гоголевской тройки еще не раз будет появляться в литературе и критике (см.: [Кошелев], [Мароши]). В сороковые годы к нему обращается В. А. Соллогуб в повести «Тарантас». Ее главный герой - Иван Васильевич - предстает как пародия на юного славянофила, который «пошатался» по Европе, «видел много трактиров, и пароходов, и железных дорог» ${ }^{4}$, разочаровался в ней и вернулся на родину патриотом, жаждущим обретения народности. «Тарантас» пестрит пародийными и ироничными эпизодами, построенными на развенчании высоких замыслов и суждений героя-славянофила при столкновении с обыденной действительностью. Впавший в уныние и отчаявшийся отыскать народность, к концу повествования герой все же обретает на миг чаемое преображение Руси. Тарантас, на котором Иван Васильевич возвращается в родное поместье где-то в глубине России, с самого начала претендует если не на символ, то на аллегорию русской 
жизни с ее несообразностью и практичностью, внешней неустроенностью и надежностью. В последней главе он проявляет свою фантастическую сущность, во сне Ивана Васильевича превращаясь сначала в таракана, затем в птицу, потом в фантастического гипогрифа. Пролетев на сказочном существе через узкую и страшную пещеру, населенную жуткими фантомами (в том числе и «народным» медведем, играющим «плясовую на балалайке» (Соллогуб, 267)), стремящимися поглотить его, герой с удивлением видит дивную картину счастливого и великого, исполненного народности будущего России.

Тарантас перерождается, в него впрягается ретивая трой$\kappa a$ и смело несется с быстротой ветра. Аллюзия на гоголевский финал «Мертвых душ» становится очевидна. То же чувство простора и восторга, но у Соллогуба оно обретает пародийные оттенки и отягчается множеством бытовых подробностей счастливо преображенной Руси. Меняются и знакомцы Ивана Васильевича. Граф, бывший дотоле западником самого дурного толка и презиравший свое отечество, вдруг становится патриотом, прославляет арзамасскую школу живописи, рассуждает о том, что в России «есть свой запад, свой восток, свой юг и свой север» (Соллогуб, 273), и даже проповедует идею о богоизбранности русского народа:

«Мы шли спокойно вперед, с верою, с покорностью и с надеждой. <..> Бог благословил наше смирение. Вы знаете, Россия никогда не заносилась духом гордыни, никогда не хотела служить примером прочим народам, и оттого-то Бог избрал Россию» (Соллогуб, 274).

Эти убеждения, сокровенные для славянофилов, горячо проповедуемые Гоголем в «Выбранных местах из переписки с друзьями», в устах пародийного героя Соллогуба обесцениваются, выглядят странно, и потому нелепо. Несостоятельность явленного идеала счастливого будущего подчеркивает и финал повести. На самом пике восторга герой вместе со всем казавшимся несокрушимым тарантасом опрокидывается в грязь - так отвечает реальность на мечты славянофила. Полет, исполненный у Гоголя лирически-пророческого чаяния, у Соллогуба оборачивается иронией, но это, в понимании автора, не демонический хохот злого духа, а веселый и здоровый смех 
прагматического здравого смысла. Как и у Гоголя, горизонталь пространства сменяется вертикалью, но уже не взлетом в неведомую высь, а резким падением вниз, но не во ад, а в грязь повседневности.

Гораздо более иронично, чем сам Соллогуб, к герою его отнесся Белинский, весьма экспрессивно в статье о «Тарантасе» обрушившись на Иванов Васильевичей, обличая как всех славянофилов, так и конкретно намекая на Ивана Васильевича Киреевского. Б. Н. Тарасов напоминает, что «умиравший от чахотки» Белинский «совершал ежедневные прогулки к вокзалу строившейся Николаевской железной дороги и с нетерпением ожидал завершения работ, надеясь на капиталистическое развитие страны в деле созидания гражданского общества и нравственного совершенствования его членов. Белинский думал, что железные дороги победят тройку» (курсив мой. - Ю. С.) [Тарасов, 2001а: 6]. Будучи западником, он чаял промышленного и научного переворота, победы цивилизации над иррациональностью и хаотичностью (с его точки зрения) русского бытия и быта. Ажиотажу Белинского Б. Н. Тарасов противопоставляет точку зрения Тютчева, который писал С. С. Уварову в 1851 г.: «Я далеко не разделяю того блаженного доверия, которое питают в наши дни ко всем этим чисто материальным способам, чтобы добиться единства и осуществить согласие и единодушие в политических обществах. Все эти способы ничтожны там, где недостает духовного единства...» [Тарасов, 2001а: 6]. Подобным образом размышлял и Гоголь в «Выбранных местах...». В письме к «Занимающему важное место» он призывает задаться вопросами:

«Зачем эта скорость сообщений? Что выиграло человечество через эти железные и всякие дороги, что приобрело оно во всех родах своего развития и что пользы в том, что один город теперь обеднел, а другой сделался толкучим рынком да увеличилось число праздношатающихся по всему миру?» (Гоголь, 8; 352-353).

Белинский, оказавшись за границей, по свидетельству П. В. Анненкова, меняет отношение к России и Европе:

«...насколько становился Белинский снисходительнее к русскому миру, настолько строже и взыскательнее становился он 
к заграничному. С ним случилось то, что потом не раз повторялось со многими из наших самых рьяных западников, когда они делались туристами: они чувствовали себя как бы обманутыми Европой, смотрели на нее с упреком, как будто она не сдержала тех обещаний, какие надавала им втихомолку» [Анненков: 592].

Но в трудах Белинского переосмысление Европы отразиться не успело. Своего рода «завещанием», квинтэссенцией его взглядов на Россию стало письмо к Гоголю по поводу «Выбранных мест из переписки с друзьями». Смело беря на себя роль выразителя мнения всего народа, Белинский пишет, что «Россия видит свое спасение не в мистицизме, не в аскетизме, не в пиетизме, а в успехах цивилизации, просвещения, гуманности» [Белинский, 1956: 213].

Как известно, Гоголь не отправит Белинскому первый вариант ответного письма, написанного в развернутой полемической форме. Пожалуй, наиболее ярким возражением критику станут публицистические и художественные произведения Достоевского, написанные после каторги, и они будут тем убедительнее, что до ареста писателю были близки идеалы «прогресса». Символично, что одной из причин ареста Достоевского стало именно публичное чтение того самого письма Белинского Гоголю.

В историософских раздумьях о судьбе России Достоевский также обращается к образу тройки ${ }^{5}$ и мотиву скачки, быстрого и безудержного передвижения в пространстве. В историософском аспекте одним из ключевых этот мотив становится в «Бесах». Как отмечает Ф. Б. Тарасов, он задается уже эпиграфами: «Кружение в поле в стихотворении через евангельский текст коррелирует с падением свиней, в которых вошли бесы, в озеро и их гибелью в пучине как потенциальным итогом уклонения России от пути, приводящего к “ногам Иисусовым”» [Тарасов, 2001b: 408]. Комментарий Степана Трофимовича к евангельскому фрагменту в финале романа подчеркивает вектор этого хаотического движения, связь символики евангельского текста с Россией: бесы должны покинуть ее и низвергнуться с обрыва, Россия же - прекратить бешеный бег, успокоиться и, наконец, остановиться, замереть у «ног Иисусовых». Бешеный полет тройки (ассоциации с финалом 
«Мертвых душ» угадываются в замысле Достоевского), тем самым, должен окончиться не инфернальным крахом, но божественным воскресением. Характерно, что Гоголю, для того, чтобы показать полет тройки ввысь, не понадобилось «ссаживать» с нее «жулика» Чичикова. В художественном же мире Достоевского оказывается, что «бесы», за которыми скрываются конкретные люди, должны все-таки покинуть тройку, чтобы бег ее мог, наконец, достигнуть священной цели. «Полет» у Достоевского окрашивается инфернальными красками, место по-своему безобидного Чичикова захватывают одержимые нигилисты во главе с «лукавым змием» Петром Степановичем - такая трансформация обусловлена стремительным ходом самой русской истории.

Распространена точка зрения, согласно которой в финале «Мертвых душ» «Гоголь не указывает путей к грядущему и светлому обновлению (обстоятельство, ядовито отмеченное в романе <"Братья Карамазовы"> прокурором)» [Ветловская: 188], тогда как у Достоевского этот полет получает чаемый - пусть не в настоящем, но в прозреваемом будущем счастливый конец: замереть у «ног Иисусовых». Вместе с тем, цель эта (не только в области возможных трактовок, но буквально в тексте) появляется и у Гоголя, в лирическом отступлении рисующего образ грешника, поверженного к ногам Спасителя:

«...может быть, в сем же самом Чичикове страсть, его влекущая, уже не от него, и в холодном его существовании заключено то, что потом повергнет в прах и на колени человека пред мудростью небес» (Гоголь, 6; 242; курсив мой. - Ю. С.).

Также и в «Выбранных местах...», развивая метафору движения от бесприютного скитальчества к обретению дома, автор пророчески призывает русских писателей «воспитаться» «христианским, высшим воспитаньем», и тогда

«скорбью ангела загорится наша поэзия и, ударивши по всем струнам, какие ни есть в русском человеке, внесет в самые огрубелые души святыню того, чего никакие силы и орудия не могут утвердить в человеке; вызовет нам нашу Россию - нашу русскую Россию <...> все до единого, каких бы ни были они различных мыслей, образов воспитанья и мнений, скажут в один голос: 
“Это наша Россия; нам в ней приютно и тепло, и мы теперь действительно у себя дома, под своей родной крышей, а не на чужбине” (Гоголь, 8; 409).

Непосредственно к образу гоголевской тройки обратится Достоевский в «Братьях Карамазовых», сделав трактовку финала «Мертвых душ» одним из центральных пунктов спора прокурора и адвоката. Первый в неистовстве Мити увидит эмблему современной России, подобно гоголевской тройке несущейся вперед без удержу и цели. Адвокат, напротив, в тех же знамениях времени усмотрит повод для гордости за отечество и пророчество о его великом и торжественном будущем не безумном беге ошалелой тройки, но плавном и горделивом движении колесницы. Как аргументированно показывает $Ф$. Б. Тарасов, в свете аллюзий на евангельский текст противопоставление тройки и колесницы оказывается мнимым [Тарасов, 2001b: 410].

И прокурор, и адвокат стремятся выстроить свою речь с точки зрения здравого смысла, понимаемого - что примечательно 6 - ими совершенно по-разному. При этом прокурор, развивая «психологию на всех парах», будет ссылаться на «тревожные голоса из Европы» (Достоевский, 15; 150), адвокат же, напротив, станет апеллировать к «правде русской», у которой «дух и смысл, спасение и возрождение погибших» (Достоевский, 15; 173). Однако славянофильский пафос адвоката тут же разобьется о модное словечко «клиент», вставленное им в речь (Достоевскиц̆, 15; 173).

И прокурор, и адвокат не выходят за рамки «горизонтального измерения», замыкаются в нем и потому не в силах постигнуть пафоса полета тройки ввысь. Рассуждения их обоих оказываются внешними и потому неадекватными по отношению к истории и пути Дмитрия Карамазова: «...позитивистская “совокупность фактов" <...> приводит к несправедливому судебному решению, внешнему по отношению к истинному “греху" героя. Таким образом, вина и наказание фактически выносятся из сферы “правового пространства” [Есаулов, 2017: 169] (см. также: [Русская классическая литература.... 195-196]).

Сюжет о тройке в речи прокурора подготовляется всем предыдущим ходом романа, наполненного бешеной ездой 
(см.: [Крюков]). Как становится известно из «Исповеди горячего сердца», Митя немало катался на тройках и любил быструю, безудержную езду. На тройке уедет в Мокрое Грушенька к «ее первому» и «бесспорному». На тройке помчится за нею Митя, и на тройках же приедет под утро за ним «все начальство». В. Е. Ветловская, рассуждая о символах в «Братьях Карамазовых», усматривает в нарочитой повторяемости суммы «три тысячи» ее «символическое значение», обозначающее «вообще какое-то наследство», «материальную сторону дела (в том широком плане, в каком толкует ее Достоевский)» [Ветловская: 267]. По аналогии можно заметить, что и тройка лошадей включается в числовой карнавал романа, вероятно, помимо пасхального гоголевского смысла, обретая и другой инфернальный смысл безудержья карамазовского, свойственный не только Карамазовым, но и всем русским людям ${ }^{7}$. Безудержья, от которого Руси-тройке нужно опомниться, очиститься и замереть у «ног Иисусовых».

Очевидно сходство бешеной езды Дмитрия Карамазова на тройке в Мокрое и “"аллегорического" финала» его блужданий - «"странного" сна» с финалом первого тома «Мертвых душ» [Ветловская: 188], впрочем, еще до того герой не раз ощутит вертикаль бытия. Внутренний мир его изначально «широк», и «горячее сердце» разрывается между низостью «идеала содомского» и высотой «идеала Мадонны». Отчетливо в художественном мире романа обе бесконечности встают перед Митей во время бешеной скачки в Мокрое.

Этот стремительный полет открывает для Мити и бесконечность неба, и бездну ада. В начале пути, освеженный быстрой ездой герой смотрит на крупные звезды, сияющие на чистом небе: «Это была та самая ночь, а может, и тот самый час, когда Алеша, упав на землю, "исступленно клялся любить ее во веки веков”» (Достоевскиц̆, 14; 369), - находит нужным пояснить рассказчик, тем самым объединяя братьев в созерцании бесконечности неба. Однако если Алеша станет «твердым на всю жизнь бойцом» и укрепится в вере, то у Мити пока «смутно» на душе. Но он уже оказывается способным признать право другого человека на счастье (того, кого и обозначит затем Вяч. Иванов как «Ты еси»), уступить Грушеньку «ее первому»: 
«И никогда еще не подымалось из груди его столько любви к этой роковой в судьбе его женщине, столько нового, не испытанного им еще никогда чувства, чувства неожиданного даже для него самого, чувства нежного до моления, до исчезновения пред ней» (Достоевский, 14; 370).

Так уже теперь для Мити через сладострастный «идеал содомский» в Грушеньке начинает проступать «идеал Мадонны».

Вместе с тем, героя посещают мысли о самоубийстве. Наравне с созерцанием звезд является и иной образ: «Во ад? <...> попадет Дмитрий Федорович Карамазов во ад али нет, как по-твоему?» - с истерическим хохотом спрашивает Дмитрий кучера Андрея, на что тот рассказывает народную легенду про Ад и с искренней наивностью отвечает Мите: «Не знаю, голубчик, от вас зависит» (Достоевский, 14; 371-372). Заканчивается скачка исступленной молитвой Мити, но не о грядущем или минувшем, а о настоящем:

«Не суди, потому что я сам осудил себя; не суди, потому что люблю тебя, Господи! Мерзок сам, а люблю тебя: во ад пошлешь, и там любить буду и оттуда буду кричать, что люблю тебя во веки веков... Но дай и мне долюбить... здесь, теперь долюбить, всего пять часов до горячего луча твоего...» (Достоевский, 14; 372).

В «реальности» событий романа скачка в Мокрое станет для Мити последней, оборвется с его арестом, назад в город его уже повезут (пассивность героя подчеркнута названием главы - «Увезли Митю»). Однако наравне с «действительностью» в романное повествование входит сон Мити, становясь ключевым для перерождения героя. Во сне он едет уже не на лихой тройке, но в телеге, запряженной «двойкой» (тем самым - на уровне символики чисел - размыкается инфернальный круг карнавального кружения на тройках). Хоть и «лихо» пролетает он мимо стоящих у дороги женщин, но оказывается способным заметить и выделить одну из них с плачущим дитём на руках. «Горячее сердце» Мити разрывается от жалости к плачущему ребенку. Вкупе с состраданием он обретает и осознание собственной вины, перед ним открывается путь покаяния и искупления вины через страдание. Вместе 
с тем, целый ряд деталей позволяет соотнести Митю и с плачущим «дитём» [Моррис: 621].

Знаменательно, что не только Митя едет этой ночью кудато - семичасовым поездом по железной дороге уезжает в Москву другой брат - Иван.

В художественном мире Достоевского железные дороги занимают особое место, в метафорическом восприятии их писатель сходится с Гоголем, Тютчевым и другими русскими мыслителями (см.: [Сытина]). Нечто зловещее образу железной дороги придает и Л. Н. Толстой в «Анне Карениной», а затем в «Крейцеровой сонате». Стоит заметить, что как некий инфернальный символ железная дорога выступает порою и у «прогрессистки» настроенных авторов. Так, мистическим ужасом наполняет ее образ Некрасов в одноименном стихотворении:

Прямо дороженька: насыпи узкие, Столбики, рельсы, мосты.

А по бокам-то всё косточки русские...

Сколько их! Ванечка, знаешь ли ты?

Чу, восклицанья послышались грозные!

Топот и скрежет зубов;

Тень набежала на стекла морозные...

Что там? Толпа мертвецов! ${ }^{8}$

И хотя рассказчик пытается ободрить Ваню тем, что русский народ «Вынесет всё, что Господь ни пошлет! / Вынесет всё и широкую, ясную / Грудью дорогу проложит себе» (Некрасов, 170), заканчивается стихотворение «отрадной» картиной пьяного народного разгула.

Метафизическое значение железной дороги оказывается в центре полушутовских, полусерьезных ““ученых” споров» в «Идиоте». Гостей князя Мышкина, как и его самого, крайне занимает толкование Лебедевым Апокалипсиса, а именно его видение «Звезды Полыни» в сети железных дорог. В пылу «проповеди» Лебедев разъясняет, что боится «не железных путей сообщения, <...> а всего того направления, которому железные дороги могут послужить, так сказать, картиной, выражением художественным» (Достоевский, 8; 311). Лебедев с жаром поясняет, что комфорт и прогресс ведут к ослаблению 
«источников жизни», и в подтверждение рассказывает историю о человеке двенадцатого столетия, который съел за жизнь свою «шестьдесят монахов и несколько светских младенцев» (Достоевский, 8; 312), а затем раскаялся и донес на себя. Из такого глубокого и искреннего покаяния Лебедев делает патетический вывод:

«...была же мысль сильнейшая всех несчастий, неурожаев, истязаний, чумы, проказы и всего того ада, которого бы и не вынесло то человечество без той связующей, направляющей сердце и оплодотворяющей источники жизни мысли!» (Достоевскиц̆, 8 ; 315).

Теперь же, «в наш век пороков и железных дорог», герой не усматривает «связующей силы», но напротив, видит оскудение духа:

«Богатства больше, но силы меньше; связующей мысли не стало; всё размягчилось, всё упрело и все упрели!» (Достоевскиц̆, 8; 315).

Неистовая проповедь Лебедева возбуждает всеобщий смех и недоумение, единственным благосклонным слушателем его оказывается князь Мышкин.

Интересно, что спустя почти десятилетие уже от своего лица в «Дневнике Писателя» 1876 года Достоевский вернется к этой логике доказательства упадка духа, несмотря (или вследствие?) роста прогресса и «гуманности», причем воспользуется образами тройки и железной дороги. Рассуждая о «Российском обществе покровительства животным» и с иронией отмечая важность того, что ““бществу” дороги не столько скоты, сколько люди, огрубевшие, негуманные, полуварвары, ждущие света!» (Достоевскиц̆, 22; 26), писатель припоминает случай из своей юности. По дороге из Москвы в Петербург они с братом и отцом стали свидетелями страшной сцены: фельдъегерь, выпив водки на станции и вновь вскочив в тележку, начал методически бить ямщика кулаком в затылок, от чего тот, в свою очередь - нещадно хлестать обезумевшую тройку. «Тут каждый удар по скоту, так сказать, сам собою выскакивал из каждого удара по человеку», — комментирует Достоевский и замечает: 
«...если 6 случилось мне когда основать филантропическое общество, то я непременно дал бы вырезать эту курьерскую тройку на печати общества, как эмблему и указание» (Достоевский, 22; 29).

Но как ни страшна нарисованная картина старых нравов, ставшая более «гуманной» современность вызывает у Достоевского больше поводов для беспокойства:

«...теперь не сорок лет назад и курьеры не бьют народ, а народ уже сам себя бьет, удержав розги на своем суде. <...> Нет фельдъегеря, зато есть “зелено-вино” (Достоевский, 22; 29).

Повсеместно растущее пьянство, «дурман», «какой-то зуд разврата», «неслыханное извращение идей с повсеместным поклонением материализму», то есть «золотому мешку» (Достоевский, 22; 30), и утрата веры отцов пугают Достоевского. Прежнее рабское поклонение перед мундиром и авторитетом сменилось признанием власти денег надо всем, ротшильдовской идеей «Подростка». Иллюстрируя современное насилие и развращенность, писатель обращается к ситуации на железHblx дорогах:

«По всей России протянулось теперь почти двадцать тысяч верст железных дорог и везде, даже самый последний чиновник на них, стоит пропагатором этой идеи, смотрит так, как бы имеющий беззаветную власть над вами и над судьбой вашей, над семьей вашей и над честью вашей, только бы вы попались к нему на железную дорогу» (Достоевский, 22; 30).

Завершает же Достоевский не призывом вернуться к прежнему, но верой в светлое будущее русских людей, которые «будут все, когда-нибудь, образованы, очеловечены и счастливы» (Достоевский, 22; 31).

В «Братьях Карамазовых» пугающая символика железной дороги возникает вновь. Иван, начав поездку в Чермашню на тарантасе, по-своему предвосхищает путь Мити в Мокрое: он также любуется ясным небом, заговаривает с извозчиком, но «не понимает» того, что отвечает мужик (Достоевский, 14; 254). Однако потом, вместо продолжения поездки в деревню, Иван предпочтет уехать в Москву по железной дороге. В символическом плане он давно уже предпочел и теоретически обосновал 
этот рациональный, механистический ориентир, теперь же только закрепляет свой выбор - и последствия его не замедлят. Железные дороги не раз появляются в романе и всегда имеют зловещий оттенок. «...Нынче век либеральный, век пароходов и железных дорог» (Достоевский, 14; 83), - провозгласит в шутовском запале Федор Павлович за монастырской трапезой. Затем «веком железных дорог» назовет свое время госпожа Хохлакова, отправляя Митю на «золотые рудники» (Достоевскиц̆, 14; 348-349). Железная дорога пересекается и с темой детства: Коля Красоткин решается испытать себя, пролежав под стремительно несущимся поездом, а выдержав испытание, он «заболел слегка нервною лихорадкой, но духом был ужасно весел, рад и доволен» (Достоевский, 14; 464). Символично, что Коля изучает железную дорогу «в подробности», живя именно на той станции, «с которой Иван Федорович Карамазов месяц спустя отправился в Москву» (Достоевский, 14; 463). Неожиданное соединение этих подробностей не важно для сюжета, но необходимо для символической подоплеки романа: становится очевидна связь новых идей, завладевающих Колей, с идеями Ивана. Безжалостность, скрытая за прогрессом, бездушность - за внешним обаянием удобства - все это настораживает, заставляет опасаться за будущее Коли и других мальчиков, за будущее самой России.

Таким образом, в русской литературе XIX в. возникают и разрастаются два символа, за которыми скрываются различные векторы развития России: «живая» птица-тройка и механическая железная дорога. И если первый отсылает к исконной самобытности и Православию, то второй - к научнотехническому и социальному «прогрессу». Оформились эти символы в споре Гоголя и К. С. Аксакова с Белинским в 1840е гг.; их позиции послужили своего рода показателями разных полюсов историософских и - исходя из этого - футурологических идей. Был в русском обществе и иной взгляд на проблему, исходящий из здравого смысла, с точки зрения которого сама проблематика споров была умозрительна и несостоятельна, ярким примером такого взгляда в литературе стал «Тарантас» Соллогуба, травестийно высмеивающий славянофильские искания современников, в том числе и Гоголя. Но подобные насмешки радикализировались и превращались в оружие в руках революционно настроенных западников - 
в данном случае Белинского, итоговые размышления которого были для графа Соллогуба гораздо более неприемлемы, чем изыскания Гоголя.

К образам тройки и железной дороги обращался Достоевский. В его реализме «в высшем смысле» они разрастаются в символы уже не просто разных путей развития России, но двух начал бытия: живого и, при всем безудержье, стремящегося к святости, и мертвого, механического, таящего в себе нечто инфернальное. В главном же Достоевский сходится с Гоголем: основополагающим у него также оказывается пасхальный архетип, свойственный всей русской культуре (см.: [Захаров, 1994], [Есаулов, 2004, 2017]).

Образы тройки и железной дороги еще не раз возникнут в русской литературе. В XX в. они столкнутся в трагическом «Сорокоусте» Есенина. Традиционно это стихотворение принято интерпретировать как победу города над деревней, однако контекст «большого» времени, представленный выше, позволяет взглянуть на есенинский текст иначе. В «Сорокоусте» «бежит по степям» «Железной ноздрей храпя, / На лапах чугунных поезд». «А за ним <..> Тонкие ноги закидывая к голове, / Скачет красногривый жеребенок». От тройки останется здесь только жеребенок, но бегущий и не сдающийся вопреки очевидности того, что «живых коней / Победила стальная конница» ${ }^{9}$ (курсив мой. - Ю. С.). Вместе с тем, последнее утверждение станет все же частью пусть риторического, но вопроса - и это, вкупе с упорством жеребенка, авторским и читательским сочувствием к нему, позволяет надеяться, что победа «стальной конницы» все-таки не является окончательной, а потому и борьба двух начал бытия, скрывающихся за символами живой тройки и механической железной дороги, продолжается.

\section{Примечания}

Исследование выполнено при финансовой поддержке РФФИ, проект «Анализ, интерпретации и понимание как методологические установки в изучении наследия Достоевского» № 18-012-90043.

1 Пушкин А. С. Полн. собр. соч.: в 10 т. М.: ГИХЛ, 1959. Т. 2. С. 383.

2 Шукшин В. М. Собр. соч.: в 4 т. М.: Литература; Престиж книга; РИПОЛ классик, 2005. Т. 4: Рассказы. С. 241. 
3 Гоголь Н. В. Полн. собр. соч.: в 14 т. М.: Изд-во АН СССР, 1952. Т. 8. С. 262. Далее ссылки на это издание приводятся в тексте статьи с указанием фамилии автора курсивом, тома и страницы в круглых скобках.

4 Соллогуб В. А. Повести и рассказы. М.: Сов. Россия, 1988. С. 193. Далее ссылки на это издание приводятся в тексте статьи с указанием фамилии автора курсивом и страницы в круглых скобках.

5 О народности образа тройки Достоевский пишет в записной книжке 1875 г.: «...все знают тройку удалую, она удержалась не только между культурными, но даже проникнула и в стихийные слои России». Достоевский Ф. М. Полн. собр. соч.: в 30 т. М.: Изд-во АН СССР, 1980. Т. 21. С. 264. Далее ссылки на это издание приводятся в тексте статьи с указанием фамилии автора курсивом, тома и страницы в круглых скобках.

6 Выпадами против здравого смьсла наполнено творчество Достоевского. Здравый смысл у него оборачивается или глупостью и ограниченностью, или преступным лукавством. Характерно, что «гость Ивана Федоровича» «оправдывает» свое богоотступничество именно здравым смыслом: «Я был при том, когда умершее на кресте Слово восходило в небо, неся на персях своих душу распятого одесную разбойника, я слышал радостные взвизги херувимов, поющих и вопиющих: “Осанна”, и громовый вопль восторга серафимов, от которого потряслось небо и все мироздание. И вот, клянусь же всем, что есть свято, я хотел примкнуть к хору и крикнуть со всеми: “Осанна!” Уже слетало, уже рвалось из груди... я ведь, ты знаешь, очень чувствителен и художественно восприимчив. Но здравый смысл - о, самое несчастное свойство моей природы - удержал меня и тут в должных границах, и я пропустил мгновение! Ибо что же, - подумал я в ту же минуту, - что же бы вышло после моей-то "осанны"? Тотчас бы все угасло на свете и не стало бы случаться никаких происшествий. И вот единственно по долгу службы и по социальному моему положению я принужден был задавить в себе хороший момент и остаться при пакостях» (Достоевский, 8; 80; курсив мой. - Ю. С.). Эмблемой здравого смысла будет для Достоевского формула «дважды два - четыре». Сомнения в ней и нежелание принимать этот постулат за истину в последней инстанции стали своего рода иллюстрацией «реализма в высшем смысле» (см.: [Захаров, 2011]).

7 Любопытно, что в «Дневнике Писателя» за 1873 год, размышляя о «вранье» как о свойстве русского человека, Достоевский, приводя примеры лжи из желания «произвесть эстетическое впечатление в слушателе, доставить удовольствие», первым делом обращается к быстрой езде: «...не случалось ли ему <читателю> раз двадцать прибавить, например, число верст, которое проскакали в час времени везшие его тогда-то лошади, если только это нужно было для усиления радостного впечатления в слушателе. И не обрадовался ли действительно слушатель до того что тотчас же стал уверять вас об одной знакомой ему тройке, которая, на пари, обогнала железную дорогу и т $<$ aК $>$ д $<$ aлее $>$ и т $<$ aК $>$ д<алее>» (Достоевский, 21; 118). 
8 Некрасов Н. А. Полн. собр. соч.: в 15 т. Л.: Наука, 1982. Т. 2. С. 169. Далее ссылки на это издание приводятся в тексте статьи с указанием фамилии автора курсивом, тома и страницы в круглых скобках.

9 Есенин С. А. Полн. собр. соч.: в 7 т. М.: Наука; Голос, 1995. Т. 2. С. 82-83.

\section{Список литературы}

1. Аксаков К. С. Несколько слов о поэме Гоголя: «Похождения Чичикова, или Мертвые души». - М.: Тип. Н. Степанова, 1842. - 19 с.

2. Анненков П. В. Литературные воспоминания. — Л.: Academia, 1928. - 661 с.

3. Белинский В. Г. Объяснение на объяснение по поводу поэмы Гоголя «Мертвые души» // Белинский В. Г. Полн. собр. соч.: в 13 т. - М.: Издво АН СССР, 1955. - Т. 6. - С. 410-433.

4. Белинский В. Г. <Письмо к Н. В. Гоголю> // Белинский В. Г. Полн. собр. соч.: в 13 т. - М.: Изд-во АН СССР, 1956. - Т. 10. - С. 212-220.

5. Ветловская В. Е. Роман Ф. М. Достоевского «Братья Карамазовы». СПб.: Изд-во «Пушкинский Дом», 2007. - 640 с.

6. Виноградов И. А. Космополит или патриот? Концепция патриотизма в спорах с Гоголем и о Гоголе // Проблемы исторической поэтики. 2017. - T. 15. - № 3. - С. 35-69 [Электронный ресурс]. - URL: http:// poetica.pro/files/redaktor_pdf/1506330606.pdf (15.08.2018). DOI 10.15393/ j9.art.2017.4461

7. Виноградов И. А. Н. В. Гоголь как славянофил: Славянская тема в наследии писателя // Проблемы исторической поэтики. - 2014. Вып. 12. - С. 199-219 [Электронный ресурс]. - URL: http://poetica.pro/ files/redaktor_pdf/1429614824.pdf(15.08.2018). DOI 10.15393/j9.art.2014.741

8. Вранчан Е. В. Функции средств передвижения в художественном мире Н. В. Гоголя: дис. ... канд. филол. наук. - Новосибирск, 2011. - 219 с.

9. Есаулов И. А. Богатырская доблесть казаков и удаль ляхов: типы героики в художественном мире Гоголя // Творчество Н. В. Гоголя и европейская культура: Пятнадцатые Гоголевские чтения. - М.; Новосибирск: Новосибирский издательский дом, 2016. - С. 275-282.

10. Есаулов И. А. Пасхальность русской словесности. - М.: Кругъ, 2004. - 560 c.

11. Есаулов И. А. Русская классика: новое понимание. - СПб.: Изд-во Русской христианской гуманитарной академии, 2017. - 550 с.

12. Есаулов И. А. Тернарная структура «Мертвых душ» (проблема преодоления апостасии) // Микола Гоголь і світова культура: Матеріали міжнародної наукової конференції, присвяченої 185-річчю з дня народження письменника). - Київ-Ніжин, 1994. - С. 86-87.

13. Захаров В. Н. Символика христианского календаря в произведениях Достоевского // Новые аспекты в изучении Достоевского. - Петрозаводск: ПетрГУ, 1994. - С. 37-49.

14. Захаров В. Н. Сколько будет дважды два, или неочевидность очевидного в поэтике Достоевского // Вопросы философии. - 2011. - № 4. C. 109-114. 
15. Захаров В. Н. Поэтика хронотопа в «Зимних заметках о летних впечатлениях» Достоевского // Проблемы исторической поэтики. - 2013. Вып. 11. - С. 180-201 [Электронный ресурс]. - URL: http://poetica.pro/ files/redaktor_pdf/1431516399.pdf (15.08.2018). DOI 10.15393/j9.art.2013.379

16. Кошелев В. А. «Время колокольчиков»: литературная история символа // Русская рок-поэзия: текст и контекст. - Тверь: ТГУ, 2000. - Вып. 3. C. $142-162$.

17. Крюков В. М. След птицы тройки. Другой сюжет «Братьев КарамазовыХ». - М.: Памятники исторической жизни, 2008. - 536 с.

18. Маркович В. М. Парадокс как принцип построения характера в русском романе XIX века. К постановке вопроса // Парадоксы русской литературы: сб. статей. - СПб.: Инапресс, 2001. - С. 158-173.

19. Мароши В. В. Тройка как символ исторического пути России в русской литературе XX века // Филология и культура. Philology and culture. 2015. — № 2 (40). - С. 204-209.

20. Мережковский Д. С. Гоголь и черт. - М.: Скорпион, 1906. - 219 с.

21. Моррис М. Где же ты, брате? Повествования на границе и восстановление связности в «Братьях Карамазовых» // Роман Ф. М. Достоевского «Братья Карамазовы»: современное состояние изучения. - М.: Наука, 2007. - С. 605-630.

22. Русская классическая литература в мировом культурно-историческом контексте / коллектив авторов под ред. И. А. Есаулова, Ю. Н. Сытиной, Б. Н. Тарасова. - М.: Индрик, 2017. - 488 с.

23. Сытина Ю. Н. Россия и Европа в полемике авторов «Московского наблюдателя» // Проблемы исторической поэтики. - 2016. - Т. 14. C. 172-184 [Электронный pecypc]. - URL: http://poetica.pro/files/ redaktor_pdf/1482920548.pdf(15.08.2018). DOI 10.15393/j9.art.2016.3602

24. Тарасов Б. Н. Куда движется история? (Метаморфозы идей и людей в свете христианской традиции). - СПб.: Алетейя, 2001. - 348 с. (а)

25. Тарасов Ф. Б. Речь Ф. М. Достоевского о Пушкине: между «тройкой» и «колесницей» // Проблемы исторической поэтики. - 2001. - Вып. 6. C. 399-419 [Электронный ресурс]. - URL: http://poetica.pro/journal/ article.php?id=2638 (15.08.2018). DOI 10.15393/j9.art.2001.2638 (b)

26. Zakharov V. N. What is Two Times Two? Or When the obvious is anything but obvious in Dostoevsky's Poetics // Russian Studies in Philosophy. 2011. - Vol. 50 (3). - Pp. 24-33.

Информация об авторе: Сытина Юлия Николаевна - кандидат филологических наук, доцент кафедры русской классической литературы Московского государственного областного университета.

Дата поступления в редакиию: 20.08.2018 
Yuliya N. Sytina

(Moscow, Russian Federation)

yulyasytina@yandex.ru

\section{"Rus', Where Are you Racing to?": from a Bird-Troika to a Railway (Gogol, Dostoevsky and Others)}

Acknowledgments. The reported study was funded by RFBR according to the research project no. № 18-012-90043.

Abstract. The article is devoted to the images of troika and railway in Russian literature of the 19th century. Russia began to develop rapidly after Peter the Great's reforms. The question of the country's development vector became particularly relevant in the 1840s. It caused the controversy of Westernizers and Slavophiles. In literature Russia's path began to be related to the metaphor of a fast movement. Gogol created the symbol of Russia as a rushing troika in the finale of the poem "Dead Souls". This symbol refers to the idea of Holy Russia. Slavophile K. Aksakov gave an enthusiastic assessment of the final lines of the poem. Westernizer Belinsky did not agree with Aksakov's interpretation. He proposed an alternative symbol of Russia as a progressive country whose symbol was a railway. V. Sologub in his story "Tarantas" ridiculed on Gogol's and Slavophiles' views on the assumption of the common sense based on which the current dispute about the choice between the Russian ways of development is speculative and unreliable. Later, Dostoevsky entered into polemics refreshing the images of a Living Troika and a Mechanic Railway. Through lens of his realism these two symbols become larger and mean not just the ways of development of Russia, but two principles of beingness - the organic, striving for the holiness, and the infernal ones. Nevertheless, Dostoevsky and Gogol coincide in the main thing - the Easter archetype is fundamental for both of them.

Keywords: N. V. Gogol, F. M. Dostoevsky, V. A. Sologub, V. G. Belinsky, symbols of the path and movement, historiosophy, Westernizers and Slavophiles

\section{References}

1. Aksakov K. S. Neskol'ko slov o poeme Gogolya: «Pokhozhdeniya Chichikova, ili Mertvye dushi" [A Few Words About Gogol's Poem: "The Adventures of Chichikov, or Dead Souls"]. Moscow, N. Stepanov Publ., 1842. 19 p. (In Russ.)

2. Annenkov P. V. Literaturnye vospominaniya [Literary Memories] Leningrad, Academia Publ., 1928. 661 p. (In Russ.)

3. Belinskiy V. G. Explanation on the Explanation About Gogol's Poem "Dead Souls". In: Belinskiy V. G. Polnoe sobranie sochineniy: $v 13$ tomakh [Belinsky V. G. The Complete Works: in 13 Vols]. Moscow, Academy of Sciences of the USSR Publ., 1955, vol. 6, pp. 410-433. (In Russ.) 
4. Belinskiy V. G. <A Letter to N. V. Gogol>. In: Belinskiy V. G. Polnoe sobranie sochineniy: $v 13$ tomakh [Belinsky V. G. The Complete Works: in 13 Vols]. Moscow, Academy of Sciences of the USSR Publ., 1956, vol. 10, pp. 212-220. (In Russ.)

5. Vetlovskaya V. E. Roman F. M. Dostoevskogo "Brat'ya Karamazovy» [F. M. Dostoevsky's Novel "The Brothers Karamazov"]. St. Petersburg, Pushkinskiy Dom Publ., 2007. 640 p. (In Russ.)

6. Vinogradov I. A. A Cosmopolitan or a Patriot? The Conception of Patriotism in Disputes with Gogol and About Gogol. In: Problemy istoricheskoy poetiki [The Problems of Historical Poetics], 2017, vol. 15, no. 3, pp. 35-69. Available at: http://poetica.pro/files/redaktor_pdf/1506330606.pdf (accessed on August 15, 2018). (In Russ.) DOI 10.15393/j9.art.2017.4461

7. Vinogradov I. A. N. V. Gogol as Slavophile: A Slavic Theme in the Writer's Heritage. In: Problemy istoricheskoy poetiki [The Problems of Historical Poetics], 2014, issue 12, pp. 199-219. Available at: http://poetica.pro/files/ redaktor_pdf/1429614824.pdf (accessed on August 15, 2018). (In Russ.) DOI 10.15393/j9.art.2014.741

8. Vranchan E. V. Funktsii sredstv peredvizheniya $v$ khudozhestvennom mire N. V. Gogolya: dis. ... kand. filol. nauk [The Functions of Means of Transport in N. V. Gogol's World. PhD. philol. sci. diss.]. Novosibirsk, 2011. 219 p. (In Russ.)

9. Esaulov I. A. The Heroism of Cossacks and the Prowess of the Poles: the Types of Heroic Spirit in the Artistic World of Gogol. In: Tvorchestvo N. V. Gogolya i evropeyskaya kul'tura: Pyatnadtsatye Gogolevskie chteniya [N. V. Gogol's Works and European Culture: The Fifteenth Gogol Readings]. Moscow, Novosibirsk, Novosibirskiy izdatel'skiy dom Publ., 2016, pp. 275-282. (In Russ.)

10. Esaulov I. A. Paskhal'nost' russkoy slovesnosti [Paskhal'nost' of Russian Literature]. Moscow, Krug Publ., 2004. 560 p. (In Russ.)

11. Esaulov I. A. Russkaya klassika: novoe ponimanie [Russian Classics: A New Understanding]. St. Petersburg, The Russian Christian Academy for the Humanities Publ., 2017. 550 p. (In Russ.)

12.Esaulov I. A. A Ternary Structure of "Dead Souls" (the Problem of Overcoming Apostasy). In: Mikola Gogol' i svitova kul'tura: Materiali mizhnarodnoï naukovoï konferenciï, prisvyachenoï 185-richchyu $z$ dnya narodzhennya pis'mennika [Nikolai Gogol and World Culture: Proceedings of the International Scientific Conference Dedicated to the 185th Anniversary of the Writer's Birth]. Kiev, Nizhyn, 1994, pp. 86-87. (In Russ.)

13. Zakharov V. N. The Symbolism of Christian Calendar in Fedor Dostoevsky's Works. In: Novye aspekty v izuchenii Dostoevskogo [New Aspects in the Study of Dostoevsky]. Petrozavodsk, Petrozavodsk State University Publ., 1994, pp. 37-49. (In Russ.) 
14. Zakharov V. N. What is Two Times Two? Or When the Obvious Is Anything but Obvious in Dostoevsky's Poetics. In: Voprosy filosofii, 2011, no. 4, pp. 109-114. (In Russ.)

15. Zakharov V. N. The Poetics of the Chronotope in Winter Notes on Summer Impressions by Dostoevsky. In: Problemy istoricheskoy poetiki [The Problems of Historical Poetics], 2013, issue 11, pp. 180-201. Available at: http://poetica. pro/files/redaktor_pdf/1431516399.pdf (accessed on August 15, 2018) (In Russ.) DOI 10.15393/j9.art.2013.379

16. Koshelev V. A. "The Time of Small Bells": A Literary History of the Symbol. In: Russkaya rok-poeziya: tekst $i$ kontekst [Russian Rock Poetry: Text and Context]. Tver, Tver State University Publ., 2000, issue 3, pp. 142-162. (In Russ.)

17. Kryukov V. M. Sled ptitsy troyki. Drugoy syuzhet "Brat'ev Karamazovykh» [The Trace of the Bird Troika. Another Plot of "The Brothers Karamazov"]. Moscow, Pamyatniki istoricheskoy zhizni Publ., 2008. 536 p. (In Russ.)

18. Markovich V. M. A Paradox as a Principle of Forming up Characters in the Russian Novel of the 19th Century. Raising a Question. In: Paradoksy russkoy literatury [Paradoxes of Russian Literature]. St. Petersburg, Inapress Publ., 2001, pp. 158-173. (In Russ.)

19. Maroshi V. V. Troika as a Symbol of Russia's Historical Path in Russian Literature of the 20th Century. In: Filologiya i kul'tura, 2015, no. 2 (40), pp. 204-209. (In Russ.)

20. Merezhkovskiy D. S. Gogol' i chert [Gogol and the Devil]. Moscow, Skorpion Publ., 1906. 219 p. (In Russ.)

21. Morris M. Where Are You, Brother? Narration on the Edge and Restoration of Coherence in "The Brothers Karamazov". In: Roman F. M. Dostoevskogo "Brat'ya Karamazovy»: sovremennoe sostoyanie izucheniya [Dostoevsky's Novel "The Brothers Karamazov": The Current State of Studying]. Moscow, Nauka Publ., 2007, pp. 605-630. (In Russ.)

22.Russkaya klassicheskaya literatura $v$ mirovom kul'turno-istoricheskom kontekste [Russian Classical Literature in the Global Cultural and Historical Context]. Moscow, Indrik Publ., 2017. 488 p. (In Russ.)

23. Sytina Yu. N. Russia and Europe as a Subject of the Dispute Between the Authors of "Moscow Observer". In: Problemy istoricheskoy poetiki [The Problems of Historical Poetics], 2016, vol. 14, pp. 172-184. Available at: http:// poetica.pro/files/redaktor_pdf/1482920548.pdf (accessed on August 15, 2018). (In Russ.) DOI 10.15393/j9.art.2016.3602

24. Tarasov B. N. Kuda dvizhetsya istoriya? (Metamorfozy idey i lyudey v svete khristianskoy traditsii) [Where Is the History Headed for? (The Metamorphosis of Ideas and People in the Christian Tradition)]. St. Petersburg, Aleteyya Publ., 2001. 348 p. (In Russ.) (a) 
25. Tarasov F. B. Fedor Dostoevsky's Speech About Pushkin: Between a Troika and a Chariot. In: Problemy istoricheskoy poetiki [The Problems of Historical Poetics], 2001, issue 6, pp. 399-419. Available at: http://poetica.pro/journal/ article.php?id=2638 (accessed on August 15, 2018). (In Russ.). DOI 10.15393/ j9.art.2001.2638 (b)

26.Zakharov V. N. What Is Two Times Two? Or When the Obvious Is Anything but Obvious in Dostoevsky's Poetics. In: Russian Studies in Philosophy, 2011, vol. 50 (3), pp. 24-33. (In English)

Information about the author: Sytina Yuliya N. - Candidate of Philology, Associate Professor, Russian Classic Literature Department, Moscow Region State University.

Received: August 20, 2018

Date of publication: December 10, 2018 